\title{
PENINGKATAN PRODUKTIVITAS KELOMPOK TANI IKAN LELE DENGAN TEKNIK BIOFLOK
}

\section{IMPROVING PRODUCTIVITY OF CATFISH FARMER GROUP WITH BIOFLOC TECHNIQUE}

\author{
${ }^{1)}$ Dwi Sudaryati, ${ }^{2)}$ Sucahyo Heriningsih, ${ }^{3)}$ Rusherlistyani \\ 1,2,3) Jurusan Akuntansi Fakultas Ekonomi dan Bisnis, UPN Veteran Yogyakarta \\ Alamat : Jl. SWK 104 (Lingkar Utara) Condong Catur, Depok, Sleman, Yogyakarta \\ Email: sudaryati_dwi@yahoo.com
}

\begin{abstract}
ABSTRAK
Lele merupakan jenis ikan yang paling banyak dimakan dan diperjualbelikan di pasar-pasar tradisional di Pulau Jawa, tak terkecuali juga di wilayah Jawa Tengah dan Daerah Istimewa Yogyakarta dan sekitarnya. Lele dijadikan salah satu jenis lauk yang bersumber dari ikan yang paling banyak diminati karena selain harganya yang relatif terjangkau masyarakat umum juga gampang diperoleh. Tujuan program pengabdian ini adalah untuk meningkatkan produktivitas budidaya ikan lele dengan teknik bioflok agar hasil panen meningkat dan mendapatkan keuntungan yang optimal. Untuk mengatasi masalah tersebut kegiatan yang dilaksanakan antara lain(1) Penyuluhan dan pendampingan teknik bioflok, (2) Penyuluhan dan pendampingan manajemen budidaya ikan lele dan (3) Pelatihan dan Pendampingan pembukuan usaha budidaya lele. Hasil kegiatan pengabdian ini ditunjukkan oleh meningkatnya motivasi mitra untuk menjalan budidaya ikan lele sebagai upaya untuk meningkatkan kesejahteraan anggota kelompok tani. Pelatihan yang telah dilakukan berhasil meningkatkan pengetahuan anggota kelompok tani untuk peningkatan produksi atau hasil panen dengan teknik bioflok, baik penanggulangan penyakit maupun cara pemeliharaan dan pemberian pakan serta peningkatan ketrampilan pembukuan.
\end{abstract}

Kata Kunci: Produktivitas, Budidaya Lele, Bioflok

\section{ABSTRACT}

Catfish is the type of fish that is mostly eaten and traded in traditional markets on the island of Java, not least in Central Java and Yogyakarta and surrounding areas. Catfish made into one type of side dish that comes from the most popular fish because in addition to the relatively affordable price of the general public is also easy to obtain. The purpose of this devotion program is to improve the productivity of catfish farming with biofloc techniques to increase yield and gain optimal benefits. To overcome the problem, the activities carried out are: (1) Counseling and mentoring of biofloc technique, (2) Counseling and guidance of catfish farming management and (3) Training and Guidance of bookkeeping of catfish farming business. The result of this dedication activity is shown by the increasing of partner motivation to run the catfish farming as an effort to improve the welfare of farmer group member. The training has succeeded in increasing the knowledge of farmer group members to increase production or harvest with biofloc technique, both disease prevention and maintenance and feeding and bookkeeping skills improvement.

Keywords: Productivity, Cultivation of Catfish, Biofloc

Submited : 10 April 2017 Revision : 20 Juni 2017 Accepted : 9 September 2017

\section{PENDAHULUAN}

Pengembangan sektor perikanan di Indonesia terlihat peningkatannya. Salah satu program Pemerintah yang terlihat adalah semakin banyaknya jumlah produksi dan peningkatan produktivitas berbagai ragam ikan baik untuk pangan 
maupun untuk ikan hias yang bersumber dari ikan air tawar dan ikan tangkapan dari lautan. Untuk jenis ikan air tawar, salah satu jenis ikan yang saat ini paling dikembangkan adalah jenis ikan keperluan pangan atau ikan konsumsi. Ikan Lele merupakan salah satu jenis ikan konsumsi yang paling banyak dibudidayakan di Jawa Tengah dan Daerah Istimewa Yogyakarta, selain Ikan Gurami, Ikan Nila (Dinas Pertanian DIY, 2012). Ikan lele mempunyai umur panen yang relative pendek yaitu antara 3 bulan dengan bibit dan keadaan kolam yang tanpa air mengalirpun bisa hidup.

Budidaya ikan lele memiliki prospek yang sangat baik dikembangkan dalam bentuk pembenihan maupun pembesaran. Permintaan konsumen akan keberadaan ikan lele semakin meningkat. Dengan teknik pemeliharaan yang baik, maka akan diperoleh hasil budidaya yang memuaskan dan diminati konsumen. Dari suatu kenyataan bahwa ikan lele merupakan makanan masyarakat yang sifatnya dimakan habis, maka permintaan akan ikan jenis ini tidak akan pernah surut. Permintaan ini tidak terbatas hanya pada permintaan local, akan tetapi peluang pasar manca Negara sangat terbuka lebar.

Dalam suatu usaha, tentunya manajemen menjadi bagian yang terpenting dalam menjalankan usaha. Seberapa bagusnya sumberdaya dan pasar, apabila memiliki manajemen yang tidak baik, maka dapat dipastikan bahwa usaha itu tidak akan bisa berhasil dan bertahan. Untuk itu managemen menjadi konsentrasi yang paling tinggi.

Mitra dalam pengabdian masyarakat ini adalah kelompok tani ikan lele yang berdiri pada tahun 2012. Kelompok tani terbentuk dari gagasan-gagasan masyarakat dengan tujuan untuk meningkatkan kesejahteraannya melalui suatu kegiatan ekonomi yang produktif dengan memanfaatkan sumber daya lokal yang ada. Wacana tersebut berkembang sehingga anggota kelompok tertarik untuk untuk melakukan budidaya ikan lele dengan modal yang tidak terlalu besar dan dilakukan pada lahan yang terbatas.

Namun, selama ini mitra melakukan budidaya ikan lele secara tradisional yaitu berdasarkan cara dan persepsi mereka masing-masing. Hal tersebut menyebabkab hasil panen ikan lele belum optimal. Salah satu faktor yang mempengaruhinya yaitu aspek pengetahuan dan ketrampilan yang dimiliki oleh anggota belum banyak sehingga mereka membudidayakan ikan lele, pemberian pakan, penanggulangan penyakit hanya menggunakan cara dan persepsi mereka sendiri. Hasil panen yang belum optimal juga disebabkan oleh tingginya biaya pakan yang mengurangi margin keuntungan anggota kelompok dalam menjalankan usaha budidaya ikan lele.

Banyak pembudidaya ikan lele yang mengalami hambatan bahkan sampai gulung tikar. Kendala yang menjadi penyebab hambatan dan kegagalan usaha, sangat bermacam-macam tetapi rata-rata penyebab utamanya adalah berkurangnya pengetahuan pembudidaya ikan lele tentang tata cara memelihara yang baik dan benar.Solusi yang atas permasalahan mitra yaitu dengan memberikan pemahaman salah satu cara budidaya ikan lele dengan teknik bioflok.

Meskipun lele termasuk dalam golongan ikan yang tahan terhadap segala jenis air, pembudidayaan yang dilakukan tanpa perlakukan khusus sudah dapat dipastikan tidak akan memberikan hasil maksimal. Untuk itu, segala cara dilakukan demi peningkatan produksi. Salah satunya, budi daya lele dengan menggunakan sistem bioflok. Menurut Setiawan,dkk (2016) bahwa teknologi bioflokulasi merupakan salah satu teknologi yang saat ini sedang dikembangkan dalam akuakultur yang bertujuan untuk memperbaiki kualilas air 
dan meningkatkan efisiensi pemanfaatan nutrisi. Teknik bioflok dinilai efektif dan mampu mendongkrak produktivitas. Ini karena dalam kolam yang sempit dapat diproduksi lele yang lebih banyak. Dengan begitu, biaya produksi berkurang dan waktu yang diperlukan relatif lebih singkat jika dibandingkan dengan budi daya secara konvensional.

Teknik bioflok memiliki keistimewaan dibandingkan budidaya dengan cara konvensional antara lain; dapat menurunkan limbah nitrogen anorganik dari sisa pakan dan kotoran, teknik ini juga dapat menyediakan pakan tambahan berprotein untuk hewan budidaya sehingga dapat menaikkan pertumbuhan dan efisiensi pakan. Teknik bioflok dilakukan dengan menambahkan karbohidrat organik kedalam media pemeliharaan untuk meningkatkan rasio $\mathrm{C} / \mathrm{N}$ dan merangsang pertumbuhan bakteri heterotrof yang dapat mengasimilasi nitrogen anorganik menjadi biomass bakteri (Crab et al., 2007). Selain itu, budidaya sistem bioflok sistem bioflok tidak berbau dan sangat baik untuk pupuk tanaman. Hal itu terjadi karena adanya mikroorganisme seperi bakteri Bacillus sp yang mampu mengurai limbah budidaya dan terbukti meningkatkan produktifitas hasil panen lele 2 kali lipat. Purnomo (2012) menyatakan bahwa penambahan sumber karbohidrat mampu meningkatkan kelimpahan bakteri pada media budidaya dan berpengaruh terhadap hasil produksi.

Beberapa penelitian menunjukkan bahwa teknik bioflok berperan dalam perbaikan kualitas air, peningkatan produktivitas, peningkatan efisiensi pakan serta penurunan biaya produksi melalui penurunan biaya pakan (Avnimelech, 2007; Setiawan, dkk., 2016; Hermawan, dkk.,2016). Keberhasilan mengelola kualitas air media budidaya ikan dengan penerapan teknik bioflok telah mengarahkan untuk menerapkan kegiatan pada mitra.

Selama ini, mitra dalam menjalankan usaha budidaya ikan lele belum melakukan pembukuan secara teratur, sehingga tidak dapat diketahui seberapa besar keuntungan maupun kerugian yang didapatkan selama menjalani kegiatan budidaya ikan lele. Dengan melihat belum adanya pembukuan sederhana tersebut maka sangat diperlukan adanya pelatihan dan pendampingan untuk pembukuan secara sederhana.Hasil panen ikan lele selama ini dipasarkan atau hanya dibeli dengan cara mendatangkan seorang pembeli. Anggota kelompok tani ikan lelebelum bisa memanfaatkan kemampuan yang dimiliki untuk mengembangan usaha budidaya lele, baik dari segi produksi maupun pasca panen.

Dengan melihat kondisi tersebut, permasalahan yang dihadapi mitra adalah anggota kelompok membudidayakan ikan lele selama ini masih menggunakan cara atau persepsi mereka sendiri-sendiri, sehingga produktivitas panen juga belum optimal. Banyak faktor yang mempengaruhinya yaitu dari aspek pengetahuan dan ketrampilan yang dimiliki oleh anggota belum banyak sehingga mereka membudidayakan ikan lele, pemberian pakan, penanggulangan penyakit hanya menggunakan cara dan persepsi mereka sendiri. Hasil panen yang belum optimal juga dapat disiasati dengan cara menekan biaya pakan, yaitu dengan cara mengembangkan teknik bioflok sehingga mitra bisa mendapatkan keuntungan semaksimal mungkin. Disamping itu, selama ini belum ada pembukuan sederhana yang diselenggarakan oleh mitra, sehingga tidak dapat diketahui seberapa besar keuntungan maupun kerugian yang didapatkan selama menjalani kegiatan budidaya ikan lele selama ini.

Berdasarkan uraian tersebut, maka tujuan kegiatan ini adalah untuk 
meningkatkan produktivitas budidaya ikan lele dengan teknik bioflok agar hasil panen meningkat dan mendapatkan keuntungan yang optimal.

\section{METODE}

Metode pendekatan yang dilakukan selama melakukan pengabdian kepada mitra adalah dengan cara diskusi, pelatihan, dan pendampingan berdasarkan masalah yang dihadapi oleh mitra. Target luaran kegiatan pengabdian ini dapat dilihat dari perilaku mitra yang berubah menjadi terbiasa dan bersemangat. Mitra menjadi mengetahui teknik budidaya lele dengan teknik bioflok. Diharapkan dengan kegiatan pengabdian ini mitra dapat meningkatkan produktivitas usaha dan kesejahteraannya.

Kegiatan pengabdian ini dimulai dengan melakukan diskusi antara tim pengabdi dengan mitra tentang rencana kegiatan. Hasil diskusi,dapat diketahui ketertarikan masyarakat terhadap kegiatan pengabdian. Selain itu, dapat membangun motivasi untuk meningkatkan produktivitas budidaya.

Kegiatan berikutnya adalah pelatihan dan pendampingan yang dilakukan dengan mengundang pakar dalam budidaya lele dengan teknik bioflok. Ada 2 orang yang akan menjadi pelatih dan pendamping dalam teknik bioflok ini. Dalam pelatihan ini maka tim pengabdian akan memfasillitasi dan menyediakan semua bahan-bahan dan peralatan yang diperlukan dalam usaha ternak lele dengan teknik bioflok tersebut. Dengan pelatihan ini diharapkan akan meningkatkan kemampuan manajemen pakan mitra dengan teknik bioflok sehingga dapat menekan biaya pakan lele dan meningkatkan produktivitas budidaya lele.
Selain, pelatihan teknik bioflok juga dilakukan pelatihan dan pendampingan tentang pembukuan sederhana yang diberikan oleh tim pengabdi sesuai dengan bidangnya. Belum adanya pembukuan yang diselenggarakan oleh pengurus maupun anggota kelompok, maka solusi yang akan dilakukan adalah pelatihan dan pendampingan pembukuan secara sederhana dalam budidaya lele; dan pelatihan pembuatan laporan keuangan secara sederhana untuk kepentingan pengajuan kredit. Diharapkan mitra mampu menyelenggarakan pembukuan secara sederhana dan dapat mengelola keuangannya dengan baik. Dengan demikian, mitra akan mampu mengembangkan usahanya.

$$
\text { Kegiatan yang lain adalah }
$$
evaluasi, yang akan dilakukan selama pelaksanaan kegiatan pengabdian yang meliputi pengamatan keterampilan dalam melaksanakan teknik bioflok dan pelaksanaan pembukuan sederhana. Selain itu juga evaluasi dilakukan untuk mengetahui keuntungan dan hambatan yang dijumpai setelah kegiatan pelatihan selesai dilakukan.

\section{HASIL DAN PEMBAHASAN}

Kegiatan Pengabdian ini didahului dengan mengadakan diskusi antara tim pengabdian dengan kelompok mitra pengabdian. Tujuan diskusi ini adalah untuk mencari dan merumuskan permasalahan sebenarnya yang dialami oleh kelompok mitra pengabdian.

Peningkatan pengetahuan dan ketrampilan mitra mengenai budidaya lele dengan teknik bioflok dilakukan melalui penyuluhan dan diskusi disertai dengan mendatangkan pelatih. Kegiatan dapat dilihat dalam gambar berikut : 


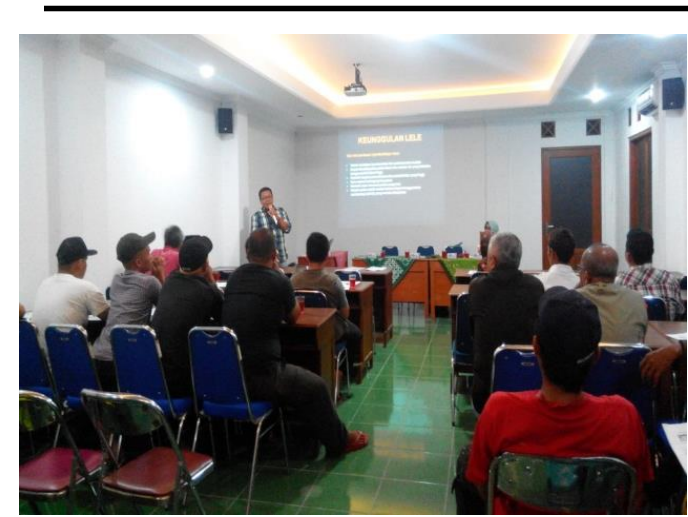

Gambar 1. Penyuluhan Teknik Bioflok

Kegiatan pengabdian dilanjutkan dengan pembuatan kolam bioflok pada mitra. Hal ini dimaksudkan untuk mengenalkan teknik budidaya lele bioflok yang dapat menekan biaya pakan dan meningkatkan produktivitas usaha lele. Selain itu, diharapkan mitra dapat membandingkan produktivitas budidaya lele dengan kolam bioflok dibandingkan dengan kolam konvensional yang selama ini telah dilakukan. Kegiatan berikutnya dengan melakukan pendampingan kepada mitra pengabdian secara rutin dan kontinyu, mulai dari membuat kolam, menebar benih hingga panen. Mitra dapat secara aktif berinteraksi dengan tim pengabdian.

Pembuatan kolam dilakukan pada lahan seluas3 meter, untuk menghemat biaya, kolam dibuat dengan terpal yang diperkuat dengan tulang/rangka dari besi.

Kolam harus diberi atap untuk menghindari terik matahari langsung dan air hujan. Sinar matahari dan air hujan perlu dihindari karena dapat memengaruhi mutu air kolam menjadi tidak layak. Peralatan lain yang perlu dipersiapkan adalah mesin aerator, yaitu alat untuk meniupkan udara ke dalam air kolam.

Lebih jelasnya dapat dilihat dalam gambar berikut :

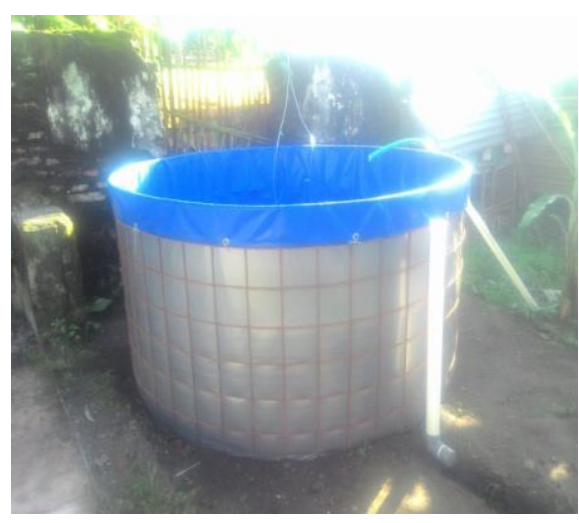

Gambar 2. Kolam Bioflok

Pada kolam bioflok yang sudah siap digunakan, mitra menebar benih ikan sebanyak 2000 ekor benihberukuran $7 \mathrm{~cm}$ dengan harga per ekor benih Rp 150,-. Selama masa pemeliharaan ada sekitar $20 \%$ (400 ekor) ikan yang mati karena tidak dapat bertahan hidup, sehingga yang tersisa sampai dengan masa panen sebanyak $80 \%$ atau 1600 ekor ikan lele.

Hal yang penting lainnya dalam budidaya lele adalah pakan, baik jenis maupun metode pemberiannya. Jika tidak tepat dalam pemberian pakan,maka tidak akan mencapai target produksi yang diinginkan, meskipun benih yang digunakan adalah benih lele yang berkualitas. Pakan adalah faktor penentu utama dalam pertumbuhan ikan lele. Menurut Craigh dan Helfrich (2002), meskipun melalui menajemen yang baik, pakan yang diberikan pada ikan pasti akan menghasilkan limbah. Dari 100 unit pakan yang diberikan kepada ikan, biasanya $10 \%$ tidak termakan, $10 \%$ merupakan limbah padatan, dan 30\% merupakan limbah cair yang dihasilkan oleh ikan. Dari sisanya, $25 \%$ digunakan untuk tumbuh dan $25 \%$ lainnya untuk metabolisme.

Pakan diberikan oleh mitra sebanyak dua kali sehari, yaitu pagi dan sore hari, dengan dosis pakan $80 \%$. Setiap seminggu sekali ikan dipuasakan, yaitu tidak diberikan pakan. Ikan dipuasakan dengan tujuan agar ikan memakan flok yang sudah 
terbentuk. Teknik bioflok bertujuan meningkatkan efisiensi pemanfaatan pakan dengan pembentukan biomassa mikroba makroagregat dari bahan organik dan senyawa terlarut (Serfling, 2006 dalam Setiawan, dkk., 2016).

Setelah dilakukan pendampingan terhadap mitra, tampak adanya perubahan pada mitra pengabdian. Mitra telah mampu merawat dan memberikan pakan yang sesuai dengan anjuran pelatih dan tim pengabdian. Setelah tiga bulan lele bisa di panen, atau setelah mencapai 8-10 ekor per kilogramnya. Panen perdana sebanyak 160 $\mathrm{kg}$ terbilang sudah cukup baik. Ini berarti bahwa tingkat keberhasilannya mencapai $80 \%$ dari $200 \mathrm{~kg}$ harapan hasil panen lele sebanyak 2.000 ekor ditebar di awal. Mengingat bahwa menurut tinjauan literatur, kehilangan pada saat dari mulai menebar benih sampai panen sebesar $30 \%$ - 35\%. Tingkat kematian sebesar 20\% saat pemeliharaan dapat disebabkan karena adaptasi maupun kepadatan pertumbuhan lele sehingga saling berebutan pakan.

Kegiatan berikutnya yang dilakukan adalah pelatihan pembukuan sederhana budidaya lele. Pada dasarnya kegiatan pembukuan merupakan usaha untuk mendokumentasikan seluruh kegiatan transaksi penerimaan maupun pengeluaran uang yang pada akhirnya dapat diketahui kondisi keuangan usaha. Manfaat kegiatan pembukuan adalah bisa mengetahui berapa kekayaan usaha, jumlah utang, jumlah piutang, serta jumlah nilai barang sediaan.

Mitra menyadari bahwa kemampuan untuk mengingat, sebagai manusia memiliki keterbatasan. Keterbatasan kemampuan mengingat ini bisa disebabkan karena kelelahan, sakit, kesibukan karena banyaknya pekerjaan sehingga tidak bisa konsentrasi. Dengan demikian jika mitra sering mengalami kelupaan, maka untuk membantu daya ingat adalah dengan membuat catatan-catatan atau tepatnya membuat pembukuan. Pembukuan dapat dilakukan dengan cara sederhana tetapi dapat diandalkan.

Manfaat dari pembukuan yang tertib adalah untuk pengambilan keputusan. Dengan melihat data-data keuangan, bisa menilai bahwa suatu usaha tengah berkembang dan memerlukan ekspansi. Tanpa data dan informasi yang komprehensif, keputusan yang dibuat bisa jadi tidak menjadi keputusan yang tepat.

Setelah dilakukan pendampingan terhadap mitra, dapat diketahui biaya-biaya tetap dan variabel dari budidaya lele serta keuntungan bersih yang didapat. Karena selama ini, hasil penjualan panen ikan lele dianggap sebagai pendapatan yang kemudian digunakan untuk memenuhi kebutuhan sehari-hari mitra.Analisa Keuangan Mitra dengan sistem bioflok, sebagai berikut:

\begin{tabular}{|c|c|c|c|}
\hline Keterangan & Jumlah & $\begin{array}{l}\text { Harga } \\
\text { Satuan }\end{array}$ & Total Biaya \\
\hline $\begin{array}{l}\text { Pembuatan } \\
\text { Kolam } \\
\text { Diameter } 3 \\
\text { Meter }\end{array}$ & 1 & 1.350 .000 & 1.350 .000 \\
\hline \multicolumn{3}{|c|}{ Total Investasi } & 1.350.000 \\
\hline \multicolumn{4}{|c|}{ Biaya Produksi Pembesaran Lele } \\
\hline $\begin{array}{l}\text { Pembelian } \\
\text { Benih Ikan } \\
\text { Lele }\end{array}$ & 2000 & 150 & 600.000 \\
\hline $\begin{array}{l}\text { Pemberian } \\
\text { Pakan Ikan } \\
\text { Lele } 3 \text { Bulan }\end{array}$ & 1 & 1.200 .000 & 1.200 .000 \\
\hline Listrik & 1 & 100.000 & 100.000 \\
\hline $\begin{array}{l}\text { Obat-obatan } \\
\text { Ikan Lele }\end{array}$ & 1 & 100.000 & 100.000 \\
\hline \multicolumn{3}{|c|}{ Total Biaya Produksi } & 1.700 .000 \\
\hline Hasil Panen & 160 & 17.000 & 2.720 .000 \\
\hline
\end{tabular}

Berdasarkan pencatatan yang telah dilakukan oleh mitra,dari hasil panen 
didapatkan keuntungan bersih sebesar $\mathrm{Rp}$ 1.020.000 (Rp 2.720.000 - Rp 1.700.000).

\section{SIMPULAN}

Secara keseluruhan kegiatan pengabdian bagi masyarakat telah melaksanakan berbagai pelatihan, penyuluhan dan pendampingan, kegiatan ini dapat terlaksana dengan baik berkat peran serta aktif dari anggota kelompok mitra. Hasil pengabdian masyarakat menunjukan bahwa pelatihan yang telah dilakukan berhasil meningkatkan pengetahuan anggota kelompok tani untuk peningkatan produksi atau hasil panen dengan teknik bioflok, baik penanggulangan penyakit maupun cara pemeliharaan dan pemberian pakan serta peningkatan ketrampilan pembukuan. Pemeliharaan dengan teknik bioflok menunjukkan kondisi yang lebih baik dan relatif ideal untuk budidaya ikan lele. Hal ini juga diperkuat dengan relatif rendahnya tingkat kematian benih selama pemeliharaan,sehingga dapat disimpulkan bahwa penerapan teknik bioflok dapat meningkatkan produktivitas tani ikan lele.

\section{DAFTAR PUSTAKA}

Crab, R., P. Bossier, Y. Avnimelech, T. Defoirdt, and W. Verstraete. 2007. Nitrogen Removal Techniques in Aquaculture for Sustainable Production. Aquaculture

Craigh S. \& Helfrich LA., 2002, Understanding Fish Nutrition, Feeds, and Feeding, Viginia Coperative Extension Service. Publication

Hermawan, TA, Agung Sudaryono dan Slamet Budi Prayitno. 2014. The Effect of Different Stocking Densities Toward Growth and Survival Rate of Catfish Seed (Clarias Gariepinus) in Biofloc Media. Journal of
Aquaculture Management and Technology Volume 3, Nomor 3, Tahun 2014.

Purnomo, P.D. 2012. Pengaruh Penambahan Karbohidrat pada Media Pemeliharaan Melalui Teknologi Bioflok Terhadap Produksi Budidaya Intensif Nila (Oreochromis niloticus). Skripsi. Fakultas Perikanan dan Ilmu Kelautan, Universitas Diponegoro. Semarang.

Rangka, Nur Ansari dan Gunarto. 2012. Pengaruh Penumbuh Bioflok Pada Budidaya Udang Vaname Pola Intensif di Tambak. Jurnal Ilmiah Perikanan dan Kelautan Vol. 4 No. 2, November 2012.

Rusherlistyani, Dwi Sudaryati dan Sucahyo Heriningsih. 2017. Manajemen Agribisnis Budidaya Ikan Lele. Penerbit: LPPM UPN Veteran Yogyakarta (ISBN: 978602-60574-1-9)

Setiawan, Rizky Ariqoh, Pratiwi Tivani, Laras Pipih dan Isti Pudjiastuti. Bioflokulasi Sistem Teknologi Budidaya Lele Tebar Padat Tinggi Dengan Kapasitas 1 $1 \mathrm{M}^{3} / 750$ Ekor Dengan Flock Forming Bacteria. Inovasi Teknik Kimia, Vol. 1, No. 1, April 2016, Hal. 45-49 ISSN 25276140. 